\title{
Geochemical and Clay-Size Minerals Evidence for the Provenance of LQC Loess Deposits in the Central Shandong, Northern China
}

\author{
Min Ding ${ }^{1,2 *}$, Junxiang Zhang ${ }^{3}$, Shuzhen Peng ${ }^{1 *}$, Wei Zhang ${ }^{1}$, Qiuyue Zhao ${ }^{1}$, Longjiang Mao ${ }^{4}$ \\ 1. The Key Laboratory of Tourism and Environment in Universities of Shandong, Taishan University, Tai'an 271000 \\ China \\ 2. State Key Laboratory of Loess and Quaternary Geology, Institute of Earth Environment, Chinese Academy of Sciences, \\ $X i$ 'an 710061, China \\ 3. School of Tourism, Huangshan Univerisity, Huangshan 245021, China \\ 4. College of Marine Science, Nanjing University of Information Science and Technology, Nanjing 210044 China
}

Received November 15, 2017

Accepted January 8, 2018

\begin{abstract}
The identification of the Shandong loess provenance adjacent to the floodplain of the Yellow River external the Loess Plateau is very important for revealing the path of dust accumulation and paleoenvironment, which has aroused widespread concern. In this study, the clay-size $(<5 \mu \mathrm{m})$ minerals and major elements composition of bulk samples and of two grain-size fractions $(<20 \mu \mathrm{m}$ and $20 \sim 63 \mu \mathrm{m})$ were analyzed in order to determine the provenance of the LongQiaoCun(LQC) loess in the Central Shandong based on comparisons with loess from the Chinese Loess Plateau and with Yellow River sediments. Statistical analysis of the sedimentary clay-size minerals reveals that LQC loess deposits in the Central Shandong adjacent to the floodplain of the Yellow River were not blown directly from the northern deserts as is the case of loess deposits in the Chinese Loess Plateau. and the Yellow River sediments may be related to erosion from the Loess Plateau. The difference in relatively immobile major element ratios of $\mathrm{TiO} 2 / \mathrm{Al} 2 \mathrm{O} 3$ and $\mathrm{K} 2 \mathrm{O} / \mathrm{Al} 2 \mathrm{O} 3$ of the $<20 \mu \mathrm{m}$ and $20 \sim 63 \mu \mathrm{m}$ fractions affirm that sediments exposed during glacial periods in the North China fluvial plain, including the floodplain of Yellow River, were the major dust source as the statistical analysis of the sedimentary clay-size minerals has concluded.
\end{abstract}

Keywords: Loess Provenance, LQC Loess, Yellow River Sediments, Chinese Loess Plateau, Geochemistry, Claysize minerals

\section{Introduction}

The identification of aeolian dust sources is important for understanding the environmental conditions (Tsoar and Pye, 1987; Sun et al., 2013; Israel et al., 2015). There has recently been increasing interest in tracing the sources of loess deposits using different methods, such as major element( Hao et al., 2010; Yang et al., 2010; Qiao et al., 2011 , 2014; Zhang et al., 2012a;Zhang et al., 2012b ; Peng et al., 2016), trace element ( Hao et al., 2010; Qiao et al., 2011; Zhang et al., 2012b ), REE (Qiao et al., 2011; Zhang et al., 2012b, Song et al., 2012 )

*Corresponding Authors:

dingmintsjy@163.com; shuzhenpeng@sohu.com and isotope ( Yang et al., 2010, Zhang et al., 2012b )..Most of those studies depend on the variation of ratios of different elements and isotopes and develop some very useful index for tracing the source of loess deposits(Hao et al., 2010; Qiao et al., 2011; Zhang et al., 2012b; Peng et al., 2016) .However, clay minerals have been widely used to ascertain Sea sediments and fluvial deposits different sources and transport paths(Liu et al.,2010, Wang et al.,2015 ) and used to reveal paleoclimatic changes as weathering index adjacent to the floodplain of the Yellow River, It is scarcely utilized to trace the sources of loess deposits in the central Shandong, northern China, there are not statistic methods to tracing the source of loess deposits, either. 
Here, based on clay-size minerals analysis, we use principal components analysis to discuss the possible for tracing the source of loess deposits in central Shandong Province adjacent to the floodplain of the Yellow River. At the same time, the relative reliable and two grain-size fractions Tracer indexes $\left(\mathrm{K}_{2} \mathrm{O} / \mathrm{Al}_{2} \mathrm{O}_{3}\right.$ and $\mathrm{TiO}_{2} / \mathrm{Al}_{2} \mathrm{O}_{3}$ ratios $)$ are used to verify.

\section{Materials and methods}

\subsection{Materials}

The study area is located at the central Shandong Mountains of North China Plain (Fig.1), it is covered with the alluvial flood plain only along the Yellow River, the rest mostly consists of the hills and low mountains, elevating between 200 $\mathrm{m}$ and $1545 \mathrm{~m}$. The region has a warm temperate and semi ${ }^{-}$ humid monsoon climate with distinct season, prevailing northwesterly wind in winter and southeasterly wind in summer, respectively. Annual temperature and precipitation are about average $12.6-14.5^{\circ} \mathrm{C}$ and $615.3-793.9 \mathrm{~mm}$ (Peng et al., 2016). Thick loess deposits in central Shandong Mountains mainly spread in the east-west direction along the northern piedmont regions of the central Shandong Mountains.

LQC loess Profile $\left(36^{\circ} 18^{\prime} \mathrm{N}, 116^{\circ} 23^{\prime} \mathrm{E}\right)$ lies at the second Yellow River terraces of Pingyin county, $2 \mathrm{~km}$ distance from the Yellow River(Fig.1). The thickness is about $7.8 \mathrm{~m}$,Its Pedosedimentary descriptions as follows: Top soils $(0 \sim 20 \mathrm{~cm})$, pale orange(7.5YR6/4),silt, lump structure, friable; Paleosol $\mathrm{S}_{0}(20 \sim 280 \mathrm{~cm})$, brown red $(7.5 \mathrm{yr} 5 / 3)$, prismatic structure, relatively firm, carbonate mycelium found in the soil; Malan loess $\mathrm{L}_{1}(280 \sim 780 \mathrm{~cm})$, Pale yellow $(7.5 \mathrm{yr} 7 / 4)$, silt, massive structure, very friable, some fine sand and Large $(2 \sim 10 \mathrm{~cm})$ $\mathrm{CaCO}_{3}$ concretions and snail shell found in the lower $\operatorname{part}(700 \mathrm{~cm} \sim 780 \mathrm{~cm})$, no bottom. In this study, we selected 5

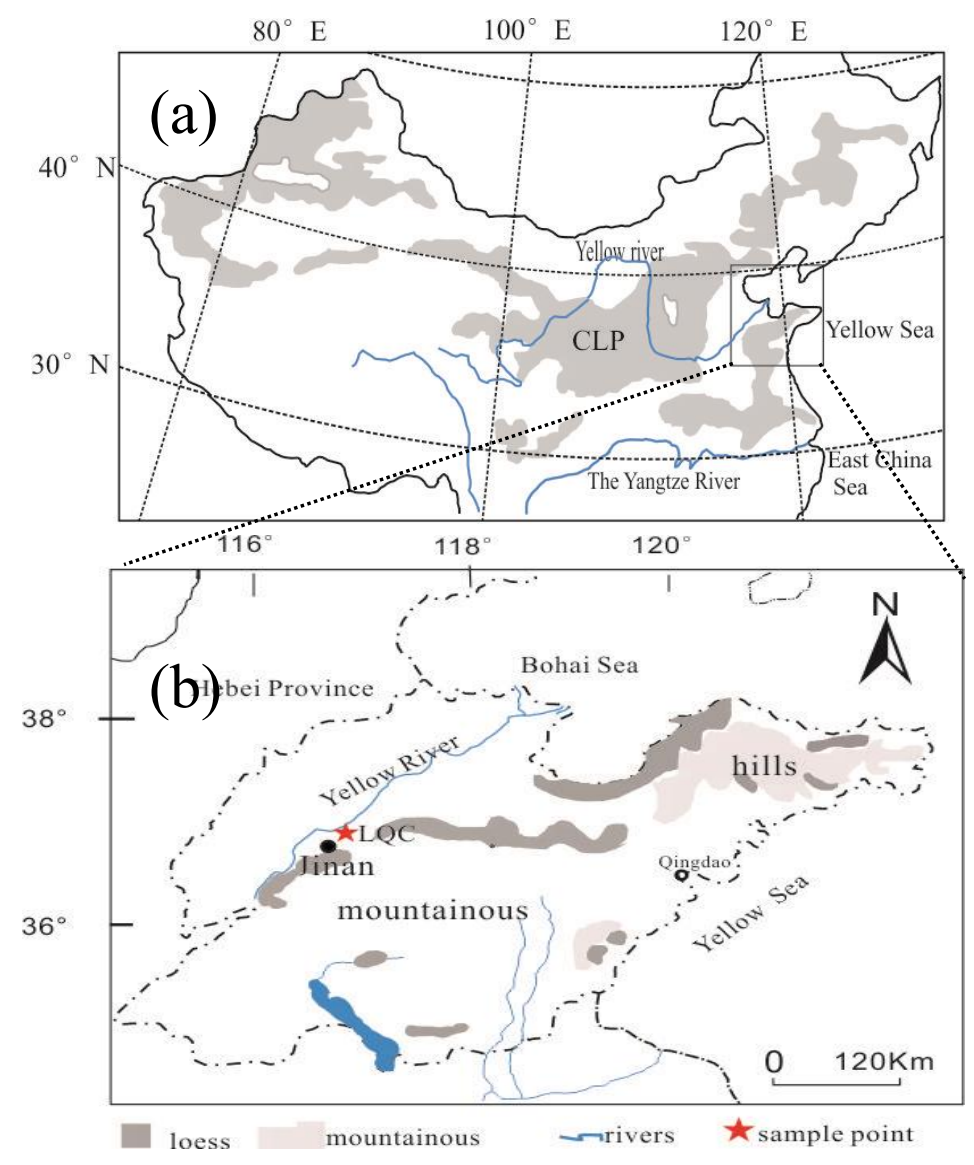

Fig.1 Location map showing loess distribution in China and the location of the sites mentioned. (a) Distribution map of loess in China and the Chinese Loess Pleatue, (b) the Shandong loess distribution in the lower reaches of the Yellow River and the sampling sites ( LQC section). 
samples of $\mathrm{L}_{1}$, which are weak in the Quaternary period, as the research object.

The eolian sediments in northwest inland and sediments of the Yellow River both are LQC loess potential provenance. Xifeng Chenjiazhuang section (XF,35 $\left.55^{\circ} \mathrm{N}, 107^{\circ} 58^{\prime} \mathrm{E}\right)$ located at the central Loess Plateau of Qingyang is a typical representative of northwest eolian sediments, is the results that the northwest desert, Gobi and other places of dust accumulation mixed, we select 6 samples of the $\mathrm{L}_{1}$ horizon as the approximate northwest dust composition. where annual mean temperature is $9.2^{\circ} \mathrm{C}$. The annual precipitation is about 527.6 mm (Peng et al., 2016).4 Yellow River sediments nearby Pingyin bridge $\left(36^{\circ} 10^{\prime} \mathrm{N}, 116^{\circ} 20^{\prime} \mathrm{E}\right)$ are sampled to compare with the LQC Loess.

\section{2 methods}

\subsection{1 geochemical analysis}

The elements samples are divided into $<20 \mu \mathrm{m}$ and $20 \sim 63 \mu \mathrm{m}$ two components to trace the source. Fine grained components of the $<20 \mu \mathrm{m}$ can move suspended below $5 \mathrm{~km}$ high Over a long distance (Hao et al., 2010; Qiao et al., 2011; Peng et al., 2016), So, Fine grained components of the $<20 \mu \mathrm{m}$ are most likely to achieve the LQC in Shandong province from the plateau and further northwest. Element ratios of $<20 \mu \mathrm{m}$ obviously advantage in source tracer (Hao et al., 2010; Qiao et al., 2011). Coarse grained components of $20 \sim 63 \mu \mathrm{m}$ mainly represents the adjacent composition. All in all, the elements ratios graded can be ignored granularity separation effect on the results (Hao et al., 2010).

Major element abundances of bulk and grain-sized were determined using a Panalytical AXIOS XRF spectrometer in the Institute of Geology and Geophysics, Chinese Academy of Sciences. To remove organic carbon and carbonate, all bulk samples of LQC and the about $25 \mathrm{~g}$ samples used by grain-size fraction were pretreated with $30 \% \mathrm{H}_{2} \mathrm{O}_{2}$ and $1 \mathrm{MOL} / \mathrm{L}$ acetic acid, respectively. Then, the samples used by grain-size fraction were infunded $10 \mathrm{ml} 0.05 \mathrm{MOL} / \mathrm{L}\left(\mathrm{NaPO}_{3}\right)_{6}$ for ultrasonic cleaning, Grained components with a $62.5 \mu \mathrm{m}$ sieve removing $>63 \mu \mathrm{m}$ components were shifted into a sedimentation cylinder, according to stokes law separation, the $<20 \mu \mathrm{m}$ component and $20 \sim 63 \mu \mathrm{m}$ component were obtained. All major element percentages were converted to oxide percentages. Analytical uncertainties are $\pm 2 \%$ for all major elements except $\mathrm{P}_{2} \mathrm{O}_{5}$ and $\mathrm{MnO}$ (up to $\pm 5 \%$ ). The geochemical data of $6 \mathrm{XF}$ samples from the Loess Plateau and the 3 floodplain samples were cited for earlier work (Peng et al., 2016).

\subsection{2 clay-size minerals measurement and minerals identification}

Clay minerals were measured by X-ray diffraction (XRD) on oriented mounts of clay-sized particles $(<5 \mu \mathrm{m})$. All samples analyzed for clay minerals were disaggregated in deionized water and treated with $30 \% \mathrm{H}_{2} \mathrm{O}_{2}$ and $1 \mathrm{~mol} / \mathrm{L} \mathrm{HAC}$ to remove organic materials and carbonate. The particles less than $5 \mu \mathrm{m}$ are then subject to pipetting based on Stokes' law. Oriented specimens were prepared on glass slides by the pipette method at room temperature.

XRD Analysis was carried out using a PANalytical X'Pert PRO X-ray Diffractometer with $\mathrm{CuK} \alpha$ radiation, operating at $40 \mathrm{kV}, 40 \mathrm{~mA}$ at Key Laboratory of Tourism and Resources Environment in Universities of Shandong, Taishan university, China. Slides were scanned from 3 to $28^{\circ} 2 \theta$ with a step size of $0.0167^{\circ} 2 \theta$ and a scan speed of $0.0711^{\circ} / \mathrm{s}$ under the air-dried, ethylene-glycol and glycerol saturated conditions for $\mathrm{Mg}$-saturated samples, and the heated to $400^{\circ} \mathrm{C}$ and $550^{\circ} \mathrm{C}$ conditions for K-saturated samples.

Identification of clay minerals was made mainly according to the position of the (001) series of basal reflections on the Multiple XRD diagrams in above-mentioned five different states (Moore and Reynolds, 1989) using the Macintosh program MacDiff (version 4.2.5) (Petschick, 2000). Curves almost under all test conditions have the same peaks: $1.41 、 1.0 、 0.71 、 0.5 、 0.47 、 0.354 、 0.334 、 0.324$ and $0.318 \mathrm{~nm}$ (Fig. 2).

Illite can be defined as a clay-size material that exhibits a rational series of reflections with ad 001 spacing of about 1.0 $\mathrm{nm}$ that does not change in ethylene glycol or glycerol saturation or after heating to 400 and $550{ }^{\circ} \mathrm{C}$ (Fig. 2) $1.0 \mathrm{~nm}$ and $0.5 \mathrm{~nm}$ peak are respectively (001) and (002) illite diffraction peak, and $0.334 \mathrm{~nm}$ peak should be superposition of diffraction peak of illite (003) and quartz (101).

According to the diffraction database, chlorite (001) series of diffraction peak position, were $1.41,0.71,0.47,0.354 \mathrm{~nm}$ in turn (Zhang et al., 2014, 2016). As Figure 2 shows, compared with the air-dried(Mg-saturated) curve, diffraction peak position of $1.41 \mathrm{~nm}$ peak in ethylene glycol saturation changed weakly, but the intensity is decreased significantly, and 0.71 , $0.47,0.71 \mathrm{~nm}$ peak position basically remain unchanged either, these features suggest chlorite contained. The diffraction characteristics of the 0.71 and $0.354 \mathrm{~nm}$ peak mean that the samples contained kaolinite in addition to chlorite, especially $\mathrm{K}$ saturated samples of $0.71 \mathrm{~nm}$ when heating to $400^{\circ} \mathrm{C}$ diffraction peak intensity is abate, the diffraction peak disappear after heating to $550{ }^{\circ} \mathrm{C}$, it is the diffraction characteristics of kaolinite. Although heating method cannot 

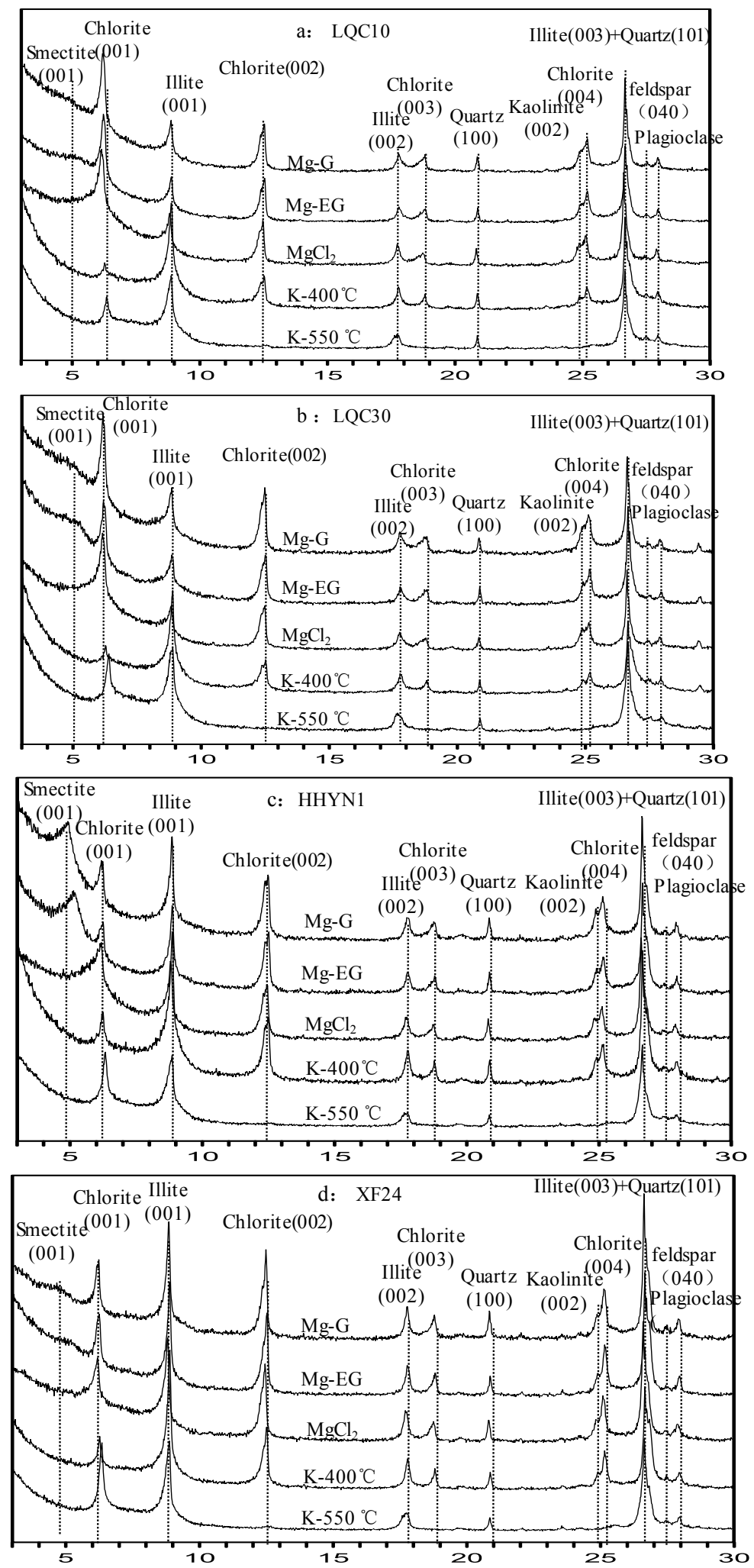

Fig.2 Multiple X-ray diffractograms of typical samples with identification and interpretation of clay-sized fractions $(<5 \mu \mathrm{m})$. (a)and (b) LQC loess samples from the CSM, (c) XF sample from the CLP, (d) the YRS in the lower reaches of the Yellow River. 
accurately identify kaolinite (Moore and Reynolds, 1989), but you can see a low $0.358 \mathrm{~nm}$ peak near by the $0.354 \mathrm{~nm}$ peak, we can accurately infer that ti is diffraction peak of kaolinite. Therefore, $0.71 \mathrm{~nm}$ peak is kaolinite (001) and chlorite (002) diffraction peak, while the peak near $0.354 \mathrm{~nm}$ is kaolinite (002) and chlorite (004) diffraction peak.

Similarly, compared with the air-dried curve (Mg-AD), the ethylene glycoled curves have a new peak at $1.75 \mathrm{~nm}$ (Fig. $2 \mathrm{Mg}$-EG and $\mathrm{Mg}-\mathrm{G})$. After saturated with glycerol (G), 1.75 $\mathrm{nm}$ peak moves to around $1.8 \mathrm{~nm}$. Although, vermiculite of $1.41 \mathrm{~nm}$ peak glyceroled also can move to a low Angle, the diffraction peak appears nearly $1.45 \mathrm{~nm}$ peak (Moore and Reynolds, 1989). this implies the occurrence of irregular mixed-layers of illite (I/S, R = 0) or smectite (Fig.2) not vermiculite.

Based on the above identifications, the clay-size minerals in the samples are illite, chlorite, $\mathrm{I} / \mathrm{S}(\mathrm{R}=0)$ or smectite. Semiquantitative estimates of peak areas of the basal reflections for the main clay mineral groups of $\mathrm{I} / \mathrm{S}(\mathrm{R}=0)$ and smectite $(1.75$ $\mathrm{nm})$, illite $(1.0 \mathrm{~nm})$, and chlorite $(0.71 \mathrm{~nm})$ were carried out on the EG curve using the MacDiff software (Petschick, 2000). The weighting factors introduced by Biscaye (Biscaye,1965) are used for each clay mineral. Additionally, other minerals were identified based on the following peaks: quartz, 0.334 $\mathrm{nm}$, feldspars, 0.324, plagioclase, $0.318 \mathrm{~nm}$ (Fig.2). Semi quantitative mineral calculation by no internal standard percentage method of Biscaye (Biscaye,1965). Semi quantitative calculation formula is as follows:

Total-area $=$ Sm-area $(001)+$ I-area $(001) \times 4+[$ Kao$\operatorname{area}(001)+\mathrm{Ch}$-area $(002)] \times 2+\mathrm{Q}$-area $(100)+\mathrm{K}$-area $+\mathrm{P}$ - area

$$
\begin{aligned}
& \mathrm{Sm} \%=\mathrm{Sm}-\operatorname{area}(001) / \text { Total-area; } \\
& \mathrm{I} \%=4 \times \mathrm{I} \text {-area }(001) / \text { Total-area; } \\
& \mathrm{Kao} \%=2 \times \mathrm{Kao}-\text { area }(001) / \text { Total-area; } \\
& \mathrm{Ch} \%=2 \times \mathrm{Ch} \text {-area }(002) / \text { Total-area; } \\
& \mathrm{Q} \%=\mathrm{Q} \text {-area }(100) / \text { Total-area; } \\
& \mathrm{K} \%=\mathrm{K} \text {-area/Total-area; } \\
& \mathrm{P} \%=\mathrm{P} \text {-area/Total-area }
\end{aligned}
$$

In the formula, $\mathrm{Sm}-$ smectite, I - illite, Kao kaolinite, Ch - chlorite, Q - quartz ( 100$)$, K feldspars, $\mathrm{P}-$ plagioclase.

\subsubsection{Statistical analysis}

Principal component analysis (PCA) statistical multivariate descriptive technique was used to explore the relationship between potential sources and loess. PCA is designed to transform the original variable into new, uncorrelated variables (axes), called the principal components.
Principal components are weighted linear combinations of the original variables. This technique provides information on the most meaningful parameters that describe an entire data set, reducing data with minimum loss of original information (Helena et al. 2000).

PCA was carried out using CANOCO4.5 (Braak and Šmilauer, 2002). The parameters used for the PCA included the all-major elements from fine and coarse-loess and potential source sediment samples.

\section{Results and analysis}

\section{1 major elements and chemical weathering}

Mean major element data of bulk samples of loess from LQC, $\mathrm{XF}$ and sediments from Yellow River are compared (Table1) The weathering stage was determined by $\mathrm{Al}_{2} \mathrm{O}_{3}-\mathrm{CaO}+\mathrm{Na}_{2} \mathrm{O}$ $\mathrm{K}_{2} \mathrm{O}$ triangular diagram (Nesbitt et al., 1980) (Fig.3). The parallel of distribution of LQC, XF and YR samples to $\mathrm{CaO}+\mathrm{Na}_{2} \mathrm{O}$ axis indicates that these samples have been only experienced weathering of the early $\mathrm{Na}$ and $\mathrm{Ca}$ removal stage, and element $\mathrm{K}$ etc. remained unchanged during the postdepositional weathering. Chemical index of alteration (CIA $\mathrm{CIA}=\mathrm{Al}_{2} \mathrm{O}_{3} /\left(\mathrm{Al}_{2} \mathrm{O}_{3}+\mathrm{CaO}^{*}+\mathrm{Na}_{2} \mathrm{O}+\mathrm{K}_{2} \mathrm{O}\right) \times 100$, in molecular proportions, $\mathrm{CaO}^{*}$ is the amount of $\mathrm{CaO}$ in the silicate minerals), widely used the chemical of terrestrial sediments (Nesbitt and Young, 1982), is also calculated. The CIA values of LQC loess deposits range from 57.3 to 60.9 (average 59.3). The CIA values of the XF loess samples from the CLP ranges from 60.2 to 61.2 (average 60.8). The CIA values of the YR sediments ranges from 57.4 to 68.5 (average 61.3). The CIA nearly equal shows that LQC, XF and YR samples is in the roughly same stage of chemical weathering degree, and reveal the same result as $\mathrm{Al}_{2} \mathrm{O}_{3}-\mathrm{CaO}+\mathrm{Na}_{2} \mathrm{O}-\mathrm{K}_{2} \mathrm{O}$ triangle.

Table2 shows that the major element data of the $<20 \mu \mathrm{m}$ fraction of sediments from LQC, XF and YR. The trace index plot shows obviously three different fields of compositions (Fig.4a). The $<20 \mu \mathrm{m}$ fractions from XF loess samples (CLP) distribute in a restricted field with high $\mathrm{K}_{2} \mathrm{O} / \mathrm{Al}_{2} \mathrm{O}_{3}$ ratios (from 0.204 to 0.210 and average to 0.207 ) and low $\mathrm{TiO}_{2} /$ $\mathrm{Al}_{2} \mathrm{O}_{3}$ ratios (from 0.059 to 0.061 and average to 0.06) (Peng et al., 2016). Those from LQC distribute in another field with Low $\mathrm{K}_{2} \mathrm{O} / \mathrm{Al}_{2} \mathrm{O}_{3}$ ratios (from 0.187 to 0.195 and average to 0.191 ) and high $\mathrm{TiO}_{2} / \mathrm{Al}_{2} \mathrm{O}_{3}$ ratios (from 0.062 to 0.072 and average to 0.067), and those of YR sediments also in a restricted field between those of CLP and CSM samples (Fig.4a).

Table 3 shows that the major element data of the $20 \sim 63$ $\mu \mathrm{m}$ fraction of sediments from LQC, XF and YR. The trace 
index plot shows that the $20 \sim 63$ fraction of sediments from CSM, CLP and SYR lies in two separated field (Fig. 4b). The 20 63 um fractions from XF loess samples (CLP) distribute in a restricted field with low $\mathrm{K}_{2} \mathrm{O} / \mathrm{Al}_{2} \mathrm{O}_{3}$ ratios (from 0.207 to 0.210 and average to 0.209 ) and $\mathrm{TiO}_{2} / \mathrm{Al}_{2} \mathrm{O}_{3}$ ratios (from 0.072 to 0.082 and average 0.077 ), The $20 \sim 63$ um fractions of sediments from LQC and YR distribute in another wide filed with overall both high $\mathrm{K}_{2} \mathrm{O} / \mathrm{Al}_{2} \mathrm{O}_{3}$ ratios (from 0.208 to 0.225 and average to 0.213 ) and $\mathrm{TiO}_{2} / \mathrm{Al}_{2} \mathrm{O}_{3}$ ratios (from 0.083 to 0.103 , and average to 0.092) (Fig. 4b)

Table1: Mean concentrations (wt \%) of major elements in the bulk deposits from the loess deposits in the LQC and the CLP, and from the YRS in the lower reaches of the Yellow River.

\begin{tabular}{|c|c|c|c|}
\hline Bulk & Long Qiao Loess & Xi Feng Loess & Yellow River Deposits \\
\hline & $(\mathrm{n}=5)$ & $(\mathrm{n}=6)$ & $(n=3)$ \\
\hline $\mathrm{SiO}_{2}$ & $76.69 \pm 1.78$ & $71.37 \pm 0.31$ & $74.50 \pm 3.33$ \\
\hline $\mathrm{Al}_{2} \mathrm{O}_{3}$ & $12.02 \pm 0.67$ & $13.96 \pm 0.16$ & $12.60 \pm 1.57$ \\
\hline $\mathrm{Fe}_{2} \mathrm{O}_{3}$ & $3.55 \pm 0.48$ & $5.20 \pm 0.10$ & $4.26 \pm 1.11$ \\
\hline $\mathrm{MnO}$ & $0.05 \pm 0.01$ & $0.07 \pm<0.01$ & $0.05 \pm 0.01$ \\
\hline $\mathrm{MgO}$ & $1.36 \pm 0.30$ & $2.28 \pm 0.04$ & $1.84 \pm 0.46$ \\
\hline $\mathrm{CaO}$ & $1.23 \pm 0.17$ & $1.47 \pm 0.05$ & $1.27 \pm 0.07$ \\
\hline $\mathrm{K}_{2} \mathrm{O}$ & $2.34 \pm 0.11$ & $2.66 \pm 0.04$ & $2.43 \pm 0.20$ \\
\hline $\mathrm{Na}_{2} \mathrm{O}$ & $2.14 \pm 0.23$ & $2.10 \pm 0.01$ & $2.20 \pm 0.24$ \\
\hline $\mathrm{TiO}_{2}$ & $0.57 \pm 0.08$ & $0.74 \pm 0.01$ & $0.70 \pm 0.12$ \\
\hline $\mathrm{P}_{2} \mathrm{O}_{5}$ & $0.08 \pm 0.03$ & $0.16 \pm<0.01$ & $0.15 \pm 0.03$ \\
\hline Total & 100 & 100 & 100 \\
\hline CIA & $59.3 \pm 1.8$ & $60.8 \pm 0.37$ & $61.5 \pm 6.25$ \\
\hline
\end{tabular}

Table2: Mean concentrations (wt \%) of major elements in the $<20 \mu \mathrm{m}$ fraction from the loess deposits in the LQC and the CLP, and from the YRS in the lower reaches of the Yellow River.

\begin{tabular}{cccc}
\hline$<20 \mu \mathrm{m}$ & Long Qiao Loess & Xi Feng Loess & Yellow River Deposits \\
\hline & $(\mathrm{n}=5)$ & $(\mathrm{n}=6)$ & $(\mathrm{n}=3)$ \\
\hline $\mathrm{SiO}_{2}$ & $62.26 \pm 2.24$ & $61.03 \pm 0.70$ & $61.65 \pm 1.14$ \\
$\mathrm{Al}_{2} \mathrm{O}_{3}$ & $17.85 \pm 0.62$ & $17.47 \pm 0.26$ & $16.78 \pm 0.44$ \\
$\mathrm{Fe}_{2} \mathrm{O}_{3}$ & $7.31 \pm 0.25$ & $7.58 \pm 0.19$ & $7.36 \pm 0.48$ \\
$\mathrm{MnO}$ & $0.07 \pm 0.01$ & $0.13 \pm<0.01$ & $0.08 \pm<0.01$ \\
$\mathrm{MgO}$ & $3.35 \pm 0.11$ & $3.68 \pm 0.09$ & $3.80 \pm 0.14$ \\
$\mathrm{CaO}$ & $3.39 \pm 2.71$ & $3.98 \pm 1.02$ & $4.39 \pm 1.13$ \\
$\mathrm{~K}_{2} \mathrm{O}$ & $3.11 \pm 0.13$ & $3.34 \pm 0.06$ & $3.08 \pm 0.04$ \\
$\mathrm{Na}_{2} \mathrm{O}$ & $1.47 \pm 0.15$ & $1.53 \pm 0.05$ & $1.55 \pm 0.14$ \\
$\mathrm{TiO}_{2}$ & $0.94 \pm 0.14$ & $0.81 \pm 0.01$ & $0.84 \pm 0.03$ \\
$\mathrm{P}_{2} \mathrm{O}_{5}$ & $0.26 \pm 0.10$ & $0.45 \pm 0.11$ & $0.47 \pm 0.11$ \\
$\mathrm{Total}$ & 100 & 100 & 100 \\
$\mathrm{CIA}$ & $58.5 \pm 5.6$ & $56.8 \pm 3.45$ & $54.9 \pm 3.42$ \\
\hline
\end{tabular}

Table3: Mean concentrations (wt \%) of major elements in the 20 63 $\mu \mathrm{m}$ fraction from the loess deposits in the LQC and the CLP, and from the YRS in the lower reaches of the Yellow River.

\begin{tabular}{cccc}
\hline $20 \sim 63 \mu \mathrm{m}$ & Long Qiao Loess & Xi Feng Loess & Yellow River Deposits \\
\hline & $(\mathrm{n}=5)$ & $(\mathrm{n}=6)$ & $(\mathrm{n}=3)$ \\
\hline $\mathrm{SiO}_{2}$ & $79.82 \pm 3.03$ & $72.92 \pm 0.80$ & $74.54 \pm 1.25$ \\
$\mathrm{Al}_{2} \mathrm{O}_{3}$ & $9.36 \pm 1.02$ & $11.10 \pm 0.19$ & $10.58 \pm 0.27$ \\
$\mathrm{Fe}_{2} \mathrm{O}_{3}$ & $2.26 \pm 0.62$ & $3.55 \pm 0.11$ & $3.25 \pm 0.32$ \\
$\mathrm{MnO}$ & $0.04 \pm 0.01$ & $0.06 \pm<0.01$ & $0.05 \pm 0.01$ \\
$\mathrm{MgO}$ & $0.98 \pm 0.40$ & $1.95 \pm 0.06$ & $1.74 \pm 0.14$ \\
$\mathrm{CaO}$ & $2.46 \pm 0.92$ & $5.12 \pm 0.56$ & $4.57 \pm 0.48$ \\
$\mathrm{~K}_{2} \mathrm{O}$ & $1.87 \pm 0.10$ & $2.14 \pm 0.05$ & $2.08 \pm 0.03$ \\
$\mathrm{Na}_{2} \mathrm{O}$ & 2.410 .12 & $2.33 \pm 0.02$ & $2.30 \pm 0.04$ \\
$\mathrm{TiO}_{2}$ & $0.7 \pm 0.05$ & $0.67 \pm 0.02$ & $0.71 \pm 0.06$ \\
$\mathrm{P}_{2} \mathrm{O}_{5}$ & $0.09 \pm 0.04$ & $0.17 \pm 0.01$ & $0.17 \pm 0.01$ \\
$\mathrm{Total}$ & 100 & 100 & 100 \\
$\mathrm{CIA}$ & $47.4 \pm 2.9$ & $41.8 \pm 1.9$ & $42.5 \pm 0.9$ \\
& & &
\end{tabular}

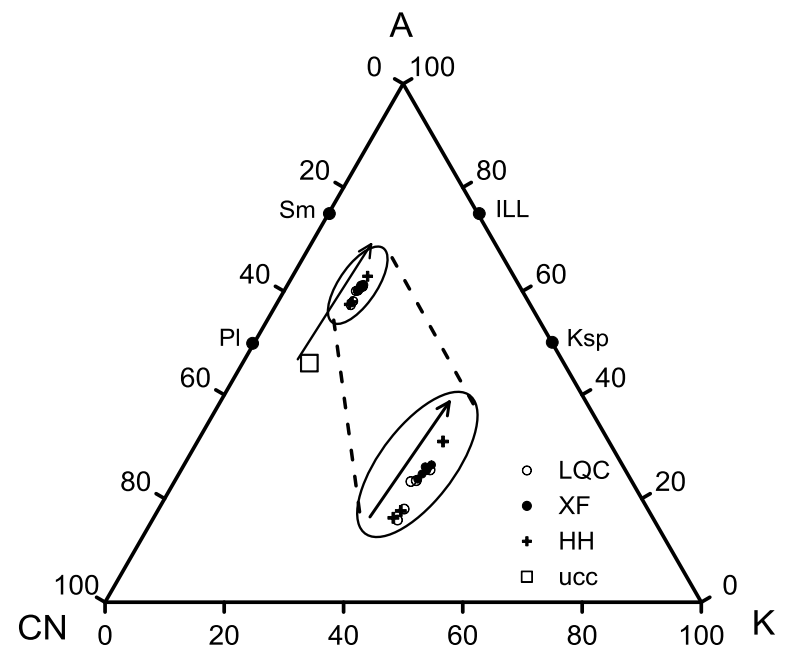

Fig. 3 A-CN-K $\left(\mathrm{Al}_{2} \mathrm{O}_{3}-\left(\mathrm{CaO}^{*}+\mathrm{Na}_{2} \mathrm{O}\right)-\mathrm{K}_{2} \mathrm{O}\right)$ diagrams of the LQC, SYR and CLP samples. (Sm, smectite; ILL, illite; Ksp, potassium feldspar; $\mathrm{Pl}$, plagioclase. $\mathrm{CaO}^{*}$ is the amount of $\mathrm{CaO}$ incorporated in the silicate fraction of the samples). 

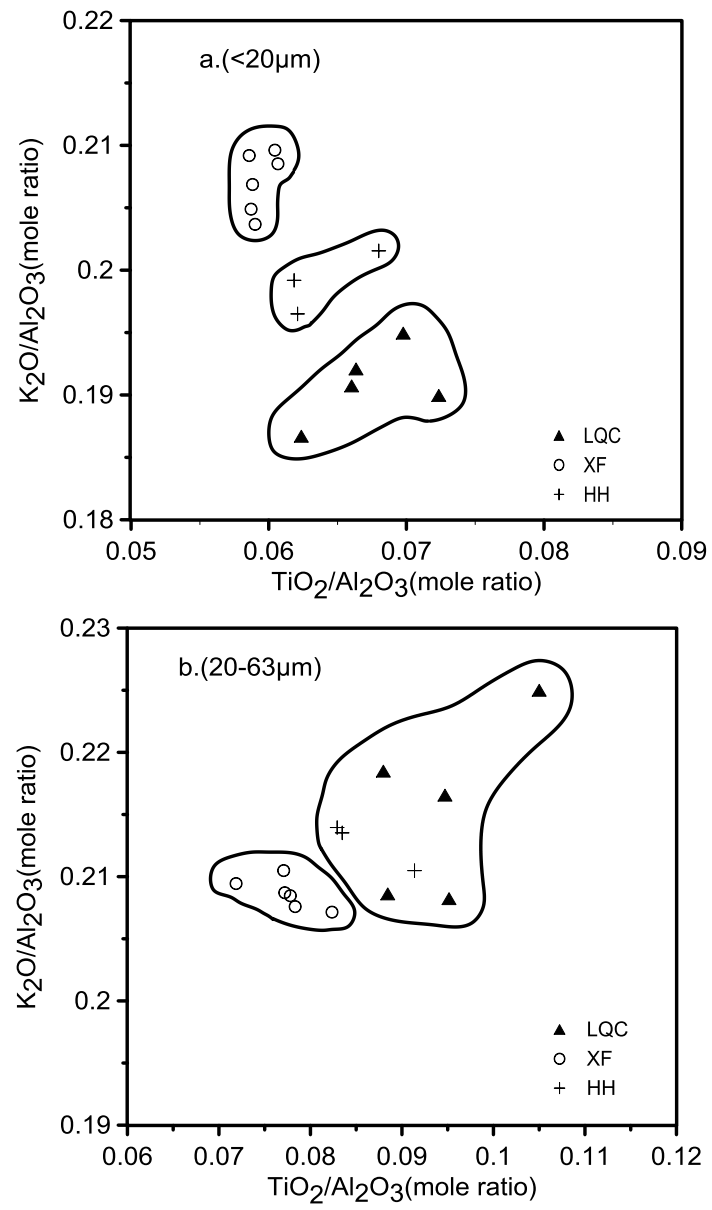

Fig.4 Plot of the $\mathrm{K}_{2} \mathrm{O} / \mathrm{Al}_{2} \mathrm{O}_{3}$ vs. $\mathrm{TiO}_{2} / \mathrm{Al}_{2} \mathrm{O}_{3}$ of the size fractions from the loess deposits in the LQC and the CLP, and from the Yellow River sediments in the lower reaches of the Yellow River.

\section{2 clay-grade mineral composition and PCA result of clay-minerals}

The clay-size minerals from LQC, XF and YR as table 4 shows. PCA of clay minerals calculated a total of 4 PCA axis which explain $100 \%$ of the variance with the data. The two main axis of PCA account for more than $94.4 \%$ of the total variance of the data set for all sampling dates(table5).

Axes 1 and 2 of a PCA of the environmental variables are shown in Figure 5. The most dominant component is axis1 representing a variance of $71.6 \%$ of the data. Almost all clay minerals are associated in this component, with strong, positive loadings from Smectite. In relation to these, axis1 also displays a negative related association of Illite, Chlorite, Plagioclase. The second dominant component is axes2 accounts for $22.8 \%$ of the data and represents positive association of Kaolinite, Quartz and Feldspar.
We calculated component or loading score, which are a linear combination of the individual samples data and the component loadings, for each individual sample from different sites. The basic rule is, the higher the concentration of clay mineral that also has a high loading in particular, the higher the score will be (Scull and Schaetzl,2011). The component score distribution will help to identify different group. Figure 5 shows the distribution of all samples in two main axis plots. The distribution in the plot reveals that three distinct sample groups. The LQC subsamples comprise one group with relative high concentration of Kaolinite, Feldspar, Smectite and Quartz and relative low concentration of Illite, Chlorite; The XF samples comprise another group with relative high Illite, Chlorite, Plagioclase and relative low concentration of Kaolinite, Feldspar, Quartz and Smectite; and the YR subsamples comprise a third group with relative high concentration of Smectite and relative low concentration of Illite, Chlorite, Plagioclase, Kaolinite, Feldspar and Quartz.

Table4. Mean concentrations (wt \%) of minerals obtained from the $<5 \mu \mathrm{m}$ fraction deposits from the LQC loess deposits in the CSM and the CLP, and from the YRS in the lower reaches of the Yellow River.

Sample Smectite Illite Kaolinite Chlorite Quartz Feldspar Plagioclase

\begin{tabular}{|c|c|c|c|c|c|c|c|}
\hline \multirow[b]{2}{*}{ LQC10 } & \multicolumn{7}{|c|}{ Long Qiao Loess } \\
\hline & 5.7 & 44.3 & 13.0 & 15.2 & 19.2 & 0.6 & 2.1 \\
\hline LQC20 & 5.9 & 46.2 & 11.1 & 14.4 & 19.8 & 0.9 & 1.6 \\
\hline LQC30 & 7.9 & 44.1 & 12.8 & 14.6 & 18.6 & 0.5 & 1.5 \\
\hline LQC40 & 3.9 & 44.7 & 11.8 & 17.5 & 19.7 & 0.7 & 1.6 \\
\hline LQC60 & 3.7 & 43.5 & 13.3 & 12.9 & 23.2 & 1.1 & 2.2 \\
\hline \multirow[t]{2}{*}{ average } & 5.4 & 44.6 & 12.4 & 14.9 & 20.1 & 0.8 & 1.8 \\
\hline & \multicolumn{7}{|c|}{ Xi Feng Loess } \\
\hline XF22 & 1.9 & 50.4 & 6.4 & 18.1 & 20.1 & 0.6 & 2.5 \\
\hline XF24 & 2.3 & 54.0 & 7.6 & 16.4 & 17.7 & 0.4 & 1.7 \\
\hline XF26 & 2.6 & 52.4 & 7.2 & 16.0 & 19.3 & 0.5 & 2.0 \\
\hline XF28 & 2.7 & 51.6 & 7.4 & 16.2 & 19.6 & 0.4 & 2.1 \\
\hline XF30 & 2.6 & 51.8 & 7.1 & 15.7 & 19.9 & 0.7 & 2.3 \\
\hline XF32 & 2.1 & 54.0 & 6.9 & 15.5 & 18.9 & 0.4 & 2.2 \\
\hline \multirow[t]{2}{*}{ average } & 2.4 & 52.4 & 7.1 & 16.3 & 19.2 & 0.5 & 2.1 \\
\hline & \multicolumn{7}{|c|}{ Yellow River Deposits } \\
\hline HHN1 & 18.8 & 43.5 & 8.8 & 12.0 & 15.2 & 0.5 & 1.3 \\
\hline HHN2 & 11.2 & 44.5 & 7.7 & 16.2 & 18.2 & 0.4 & 1.8 \\
\hline HHXS3 & 14.9 & 43.3 & 8.1 & 13.6 & 17.3 & 0.6 & 2.3 \\
\hline HHCS4 & 10.4 & 46.5 & 8.2 & 14.4 & 18.4 & 0.5 & 1.6 \\
\hline average & 13.8 & 44.5 & 8.2 & 14.0 & 17.3 & 0.5 & 1.7 \\
\hline
\end{tabular}


Table5: Loadings of clay-sized minerals on four significant principal components for samples from the LQC loess deposits in the CSM and the CLP, and from the YRS in the lower reaches of the Yellow River.

\begin{tabular}{ccccc}
\hline Sample & PC1 & PC2 & PC3 & PC4 \\
\hline Smectite & 0.951 & -0.309 & -0.012 & 0.007 \\
Illite & -0.870 & -0.472 & -0.133 & -0.045 \\
Kaolinite & 0.339 & 0.886 & -0.201 & -0.246 \\
Chlorite & -0.695 & -0.024 & 0.686 & -0.212 \\
Quartz & -0.502 & 0.721 & -0.016 & 0.475 \\
feldspar & 0.092 & 0.742 & -0.186 & 0.405 \\
plagioclase & -0.513 & 0.040 & 0.147 & 0.598 \\
Variance(\%) & 71.6 & 22.8 & 3.8 & 1.8 \\
Cumulative & 71.6 & 94.4 & 98.2 & 100 \\
variance(\%) & & & & \\
\hline
\end{tabular}

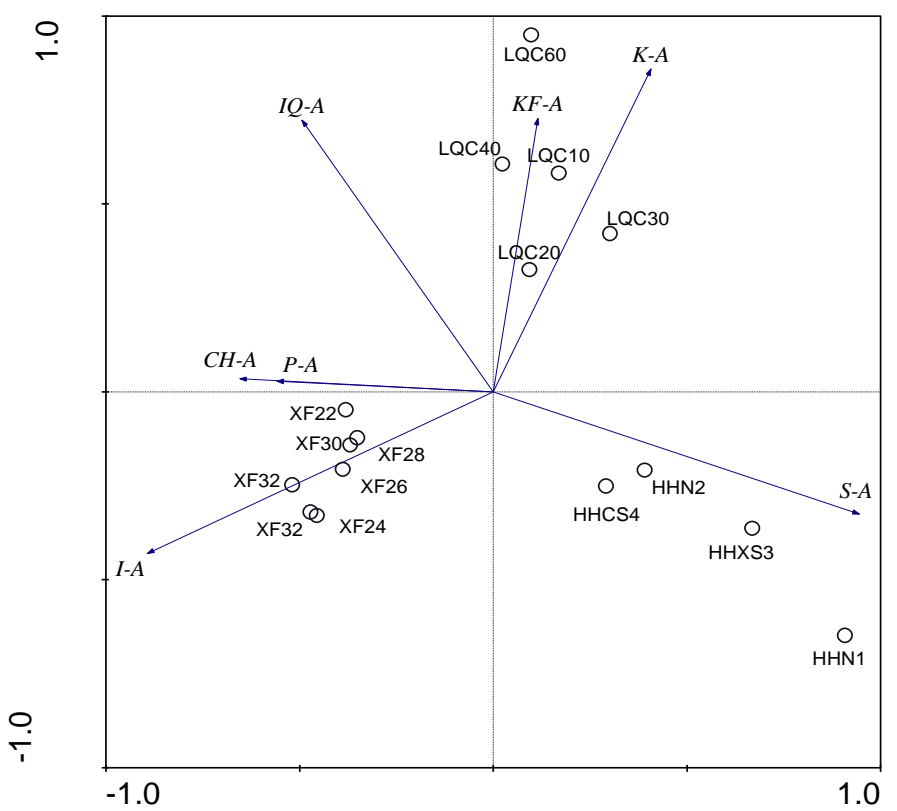

Fig.5 Principal component analysis of the minerals data obtained from clay-sized fractions $(<5 \mu \mathrm{m})$ from the LQC loess deposits in the CSM and the CLP, and from the YRS in the lower reaches of the Yellow River.

\section{Explanation for Provenance}

\subsection{Evidence from clay-sized minerals}

It shows that the LQC loess in Shandong has significantly different Clay-size Minerals composition $(<5 \mu \mathrm{m})$ with XF loess from plateau. We can conclude that the LQC loess in Shandong does not come from the loess plateau. However, Clay-size minerals composition of the LQC loess in Shandong are similar with the Yellow River sediments, therefore, we can infer that the exposed YR fluvial sediments was mainly but not the only dust source of LQC loess deposits in Shandong. Near-Source hypothesis is that loess deposits in Shandong maybe trace sediments Bohai Bay shelf, yellow river fluvial plain or Locally weathered material. Far-source hypothesis is that loess deposits in Shandong maybe trace sediments northwest of china or Loess Plateau (Hao et al., 2010; Peng et al., 2016).

Principal components $\mathrm{PCl}$ has positive correlation to Smectite content (coefficients is + 0951), and has negative correlation to unstable minerals ( Illite, chlorite and plagioclase) (correlation coefficient is less than 0.513). the Yellow River sediments(YRS) gain the highest scores, followed by LQC loess deposits, they are distributed in the right side of the first axis, the two have larger similarity, compared with the XF loess in loess plateau, Yellow River sediments (YRS) with high content of Smectite, and low content of chlorite, Illite ,plagioclase. and numerous research support the results that the Yellow River sediments has high Smectite content, and Smectite content of LQC loess deposition in Shandong is higher, too, unstable minerals, such as chlorite, illite content is low. So, we can confer that fine particles of the LQC loess is from the deposition of the Yellow River. In fact, LQC profile is located in the Yellow River on the second terrace, about $2 \mathrm{~km}$ from the Yellow River south of the Yellow River. It blows northerly, and can carry the materials of dust (Yellow River sediments ) to the LQC section, we can further deduce LQC profile fine materials mainly is from yellow floodplain sediments.

As principal components PC2 display, LQC section in Shandong is different in minerals composition from the XF section in Loess Plateau and the Yellow River deposition (YRS), kaolinite, quartz and feldspar content from LQC section is higher. However, the XF section in Loess Plateau and the Yellow River deposition (YRS) are inverse. Weathering triangle (A-CN-K) and CIA indicate that LQC, $\mathrm{XF}$ and YRS samples are all roughly in weathering of the early $\mathrm{Na}$ and $\mathrm{Ca}$ removal stage and K-feldspar without weathering, so K-feldspar and kaolinite in older weathering stage are the clastic not the Local weathering products, so, can reveal the provenance and sedimentary path. Quartz is very stable and free from weathering and can reveal changes in provenance. This feature of LQC loess with high content stable minerals differing from XF and YRS, may be related to the contribution of local weathering products. As for the Yellow River sediments and XF loess of the Loess Plateau has relatively the low content of kaolinite, feldspar, quartz, that is 
similar each other, the reason is that the two have a certain relationship. As previous studies show(Li et al.,2009), the Yellow River sediments partly come from the Loess Plateau heavily eroded in the middle reaches by the Yellow River, It flows slowly down with sediment deposition in the lower reaches of the the Yellow River, long and long, The Yellow flood plain and the North China Plain is formed.

So, the clay-size minerals show that fine materials of LQC loess partly and not only trace from the Yellow River sediments, and the Yellow River sediments come from the Loess Plateau heavily eroded loess in the middle reaches by the Yellow River.

\subsection{Evidence from major element composition}

CIA and $\mathrm{Al}_{2} \mathrm{O}_{3}-\mathrm{CaO}+\mathrm{Na}_{2} \mathrm{O}-\mathrm{K}_{2} \mathrm{O}$ triangle from the bulk samples shows that LQC, XF and YR samples is in the roughly same stage of chemical weathering degree section lies in Shandong, it is warmer and wetter than the city XF section lies in, the same as the periods of the Quaternary glaciation when we study. So, If the LQC loess comes from the Loess Plateau, the LQC loess should have higher chemical maturity. But, this is not the case. We can suppose that it is due to differences in provenance and LQC loess is indirectly from the Loess Plateau.

The ratios of the $\mathrm{TiO}_{2} / \mathrm{Al}_{2} \mathrm{O}_{3}$ and $\mathrm{K}_{2} \mathrm{O} / \mathrm{Al}_{2} \mathrm{O}_{3}$ from fractioned loess $(<20 \mu \mathrm{m}$ and $20 \sim 63 \mu \mathrm{m})$ are powerful indexes to trace the provenance of loess (Hao et al., 2012; Zhang et al., 2012; Peng et al., 2016). And the two ratios are most less affected by variations in grain-size caused by the sedimentary sorting processes and are proved valuable to trace the dust source in CSM region of china and the Southern China (Hao et al., 2012; Peng et al., 2016). Our data reveal that the LQC loess is at the early stage of weathering, characterized by removal of $\mathrm{Ca}$ and $\mathrm{Na}$ (Fig.3) and by reservation of $\mathrm{K}$, similarly to those in central CLP. Plot of $\mathrm{TiO}_{2} / \mathrm{Al}_{2} \mathrm{O}_{3}$ vs. $\mathrm{K}_{2} \mathrm{O} / \mathrm{Al}_{2} \mathrm{O}_{3}$ could provide a valuable indication of the dust source in Shan dong province of china.

The $<20 \mu \mathrm{m}$ fractions for loess from LQC loess in Shandong province, Chinese loess plateau and Yellow river sediments have distinctly different geochemical compositions (Fig. 4a). The $\mathrm{TiO}_{2} / \mathrm{Al}_{2} \mathrm{O}_{3}$ ratio of $\mathrm{LQC}$ is higher and the $\mathrm{K}_{2} \mathrm{O} / \mathrm{Al}_{2} \mathrm{O}_{3}$ ratio of LQC is lower compared to those from CLP, it precludes the possibility that the $<20$ $\mu \mathrm{m}$ fraction in the LQC samples was not directly blown from the northern deserts. The distinct $\mathrm{K}_{2} \mathrm{O} / \mathrm{Al}_{2} \mathrm{O}_{3}$ ratios of LQC from the YR sediments indicate that the YR sediments dust is not the only source as the case proved by the claysize minerals previously. As the clay-size minerals have indicated and the Previous research, the eroded loess particles are one of the major sources of suspended in the section of Yellow River when it flows through Chinese Loess Plateau. Why are the $\mathrm{TiO}_{2} / \mathrm{Al}_{2} \mathrm{O}_{3}$ and the $\mathrm{K}_{2} \mathrm{O} / \mathrm{Al}_{2} \mathrm{O}_{3}$ ratios of Yellow river sediments Obviously different from CLP? Mabey, it is the reason that significantly newly added base rock materials from the YR drainage system into the fluvial deposits of YR or the original minerals were lost from the YR drainage system (Nie et al.,2015). Thus, the $\mathrm{K}_{2} \mathrm{O} / \mathrm{Al}_{2} \mathrm{O}_{3}$ ratio of Yellow river sediments is lower than the ratio of loess from Chinese Loess Plateau is due to the loss of Illite, Smectite, mica and other clay minerals comminuting during fluvial transport. $\mathrm{K}$ often is hosted in Illite, Smectite, mica and other clay minerals (Cox et al., 1995), The loss of $\mathrm{K}$ leads to decrease of the ratio $\mathrm{K}_{2} \mathrm{O} / \mathrm{Al}_{2} \mathrm{O}_{3}$. In fact, the dominant Iillite content in the finegrained $(<5 \mu \mathrm{m}) \quad$ Yellow River sediments $(44.5 \%)$ is significantly lower than that on the Chinese Loess Plateau $(52.4 \%)$. So, it is well consistent with our inference from clay-size minerals that the fine fractions of LQC loess in Shandong province is not only blowing from Yellow River sediments.

In the case of the $20 \sim 63 \mu \mathrm{m}$ fraction the samples from LQC in Shandong have significantly different $\mathrm{TiO}_{2} / \mathrm{Al}_{2} \mathrm{O}_{3}$ ratios compared to those from Chinese Loess Plateau; and the values overlap with the ranges of values for the Yellow River samples. The fact that the $20 \sim 63 \mu \mathrm{m}$ fraction of the Yellow River samples has higher $\mathrm{TiO}_{2} / \mathrm{Al}_{2} \mathrm{O}_{3}$ ratios than those of the Chinese Loess Plateau may be mainly related to newly added base rock materials into the fluvial deposits of YR during fluvial transport(Nie et al.,2015), as is the case for the $<20 \mu \mathrm{m}$ fraction. However, the $\mathrm{K}_{2} \mathrm{O} / \mathrm{Al}_{2} \mathrm{O}_{3}$ ratio of Yellow river sediments is not lower than the ratio of loess from Chinese Loess Plateau is because the Illite, Smectite, mica ,et al.in fluvial deposits is less loss in coarse fraction than it in the fine fraction during fluvial transport in Yellow River .The significantly different $\mathrm{TiO}_{2} / \mathrm{Al}_{2} \mathrm{O}_{3}$ and $\mathrm{K}_{2} \mathrm{O} / \mathrm{Al}_{2} \mathrm{O}_{3}$ ratios of the 20 63 $\mu \mathrm{m}$ fraction of the loess samples of the Central Shandong Mountains compared to those of the Chinese Loess Plateau also support our previously-stated inference that, based on the aerodynamic characteristics of the $>20 \mu \mathrm{m}$ fraction, it is unlikely that this fraction is derived from distant sources. Furthermore, the values of $\mathrm{TiO}_{2} / \mathrm{Al}_{2} \mathrm{O}_{3}$ and $\mathrm{K}_{2} \mathrm{O} / \mathrm{Al}_{2} \mathrm{O}_{3}$ from LQC samples in Shandong overlapping with the ranges of values for the Yellow River samples infer that the $20 \sim 63 \mu \mathrm{m}$ coarse fraction of LQC loess mainly derive from Yellow River sediments. 


\section{Conclusion}

In this study, the clay-size $(<5 \mu \mathrm{m})$ minerals and major elements composition of bulk samples and of two grain-size fractions $(<20 \mu \mathrm{m}$ and $20 \sim 63 \mu \mathrm{m})$ were analyzed in order to determine the provenance of the Longqiaocun (LQC) loess in the Central Shandong based on comparisons with loess from the Chinese Loess Plateau and with Yellow River sediments.

The trace index $\left(\mathrm{TiO}_{2} / \mathrm{Al}_{2} \mathrm{O}_{3}\right.$ and $\left.\mathrm{K}_{2} \mathrm{O} / \mathrm{Al}_{2} \mathrm{O}_{3}\right)$ plot shows obviously three different fields of compositions and the trace index $\left(\mathrm{TiO}_{2} / \mathrm{Al}_{2} \mathrm{O}_{3}\right.$ and $\left.\mathrm{K}_{2} \mathrm{O} / \mathrm{Al}_{2} \mathrm{O}_{3}\right)$ plot shows that the $20 \sim 63$ fraction of sediments from CSM, CLP and SYR lies in two separated field. The difference in relatively immobile major element ratios of $\mathrm{TiO}_{2} / \mathrm{Al}_{2} \mathrm{O}_{3}$ and $\mathrm{K}_{2} \mathrm{O} / \mathrm{Al}_{2} \mathrm{O}_{3}$ of the $<20 \mu \mathrm{m}$ and $20 \sim 63 \mu \mathrm{m}$ fractions affirm the case that LQC loess deposits in the Central Shandong adjacent to the floodplain of the Yellow River were not blown directly from the northern deserts as is the case of loess deposits in the Chinese Loess Plateau.

Statistical analysis of the sedimentary clay-size minerals reveals that LQC loess deposits in the Central Shandong adjacent to the floodplain of the Yellow River discover the cause of the difference in relatively immobile major element ratios of $\mathrm{TiO}_{2} / \mathrm{Al}_{2} \mathrm{O}_{3}$ and $\mathrm{K}_{2} \mathrm{O} / \mathrm{Al}_{2} \mathrm{O}_{3}$ at LQC section. And together with the elements, we can conclude that North China fluvial plain, including the floodplain of Yellow River, was the major dust source of the LQC loess in the central Shandong adjacent to the floodplain of the Yellow River and the Yellow River sediments may be related to erosion from the Loess Plateau. This is consistent with the conclusion that the loess is the near-source deposits adjacent to the floodplain of the River(Li et al.2014).

The combination of elements and minerals is an effective means of source identification.

Acknowledgement: This study was supported by Doctor Luo Wang and National Natural Science Foundation of China $(41402319,41472313,41771218,41602353)$, National Key Laboratory of Loess and Quaternary Geology Open Fund (SKLLQG1002), Taishan University Talent Research Fund (Y-012016001). Min Ding and Shuzhen Peng both are corresponding authors.

\section{References}

H. Tsoar, K. Pye. Dust transport and the question of desert loess formation, Sedimentology, 34(1987)139-153.

J.M. Sun. Provenance of loess material and formation of loess deposits on the Chinese Loess Plateau, Earth and Planetary Science Letters, 203(2002) 845-859.

Ben-Israel M, Enzel Y, Amit R, et al. Provenance of the various grain-size fractions in the Negev loess and potential changes in major dust sources to the Eastern
Mediterranean, Quaternary Research, 83(1) (2015)105115.

Q.Z. Hao, Z.T. Guo, Y.S. Qiao, et al. Geochemical evidence for the provenance of middle Pleistocene loess deposits in southern China, Quaternary Science Reviews, 29(2324) (2010)3317-3326.

S.L. Yang, X.M. Fang, Z.T. Shi, et al. Timing and provenance of loess in the Sichuan Basin, southwestern China, Palaeogeography, Palaeoclimatology, Palaeoecology,292(2010) 144-154.

Y.S. Qiao, Q.Z. Hao, S.Z. Peng, et al. Geochemical characteristics of the eolian deposits in southern China, and their implications for provenance and weathering intensity, Palaeogeography, Palaeoclimatology, Palaeoecology, 308(2011)513-523.

Y.S. Qiao, L. Qi, Z.X. Liu, et al. Intensification of aridity in the eastern margin of the Tibetan Plateau since 300ka BP inferred from loess-soil sequences, western Sichuan Province, southwest China, Palaeogeography, Palaeoclimatology, Palaeoecology, 414(2014)192-199.

W. G. Zhang, C.Y. Dong, L.P. Ye, et al. Magnetic properties of coastal loess on the Midao islands, northern China: Implications for provenance and weathering intensity, Palaeogeography, Palaeoclimatology, Palaeoecology, 333-334(2012a)160-167.

H.Y. Zhang, H.Y. Lu, S.Y. Jiang, et al. Provenance of loess deposits in the Eastern Qinling Mountains (central China) and their implications for the paleoenvironment. Quaternary Science Reviews 43(2012b) 94-102.

S.Z. Peng, Q.Z. Hao, L. Wang, et al. Geochemical and grainsize evidence for the provenance of loess deposits in the central shandong mountains region, northern china, Quaternary Research, 85(2) (2016)290-298.

H. Song, P. B. Wignall, J. Tong, et al. Geochemical evidence from bio-apatite for multiple oceanic anoxic events during permian-triassic transition and the link with endpermian extinction and recovery, Earth \& Planetary Science Letters, s 353-354 (2012)12-21.

J.S. Fang, M.J .Barcelona, R.V. Krishnamurthy et al. Stable carbon isotope biogeochemistry of a shallow sand aquifer contaminated with fuel hydrocarbons, Appl Geochem, 15(2) (2000) 157-169.

J. G. Liu, M. H. Chen, Z. Chen, et al. Clay mineral distribution in surface sediments of the south china sea and its significance for in sediment sources and transport.Chinese Journal of Oceanology and Limnology,28(2) (2010) 407-415.

J. Wang, A. Li, K. Xu, et al. Clay mineral and grain size studies of sediment provenances and paleoenvironment evolution in the middle Okinawa Trough since $17 \mathrm{ka}$. Marine Geology, 366 (2015)49-61.

D. M. Moore, R.C. Reynolds. X-Ray Diffraction and the Identification and Analysis of Clay Minerals. New York: Oxford University Press, (1989)1-322

R. Petschick. MacDiff 4.2.5 (Online). Available: http:/www.ccp14.ac.uk/ccp/ web-mirrors/ krumm/ macsoftware/macdiff/MacDiff.htmlPetschick, 2000 
Download 01-12-2009

C. Zhang, Z. Guo, C. Deng, et al. Clay mineralogy indicates a mildly warm and humid living environment for the miocene hominoid from the zhaotong basin, yunnan, china.Scientific Reports,6(2016)20012.

C. Zhang \& Z. Guo, Clay mineral changes across the eoceneoligocene transition in the sedimentary sequence at xining occurred prior to global cooling. Palaeogeography Palaeoclimatology Palaeoecology,411(1) (2014)18-29.

P. E. Biscaye. Mineralogy and sedimentation of recent deepsea clay in the Atlantic Ocean and adjacent seas and oceans, Geological Society of America Bulletin, 76(1965) 803-832.

B. Helena, R. Pardo, M. Vega, et al. Temporal evolution of groundwater composition in an alluvial aquifer (Pisuerga River, Spain) by principal component analysis, Water Research, 34(3) (2000)807-816.

Braak, C.J.F. ter, \& Smilauer, P. Canoco reference manual and canodraw for windows user's guide: software for canonical community ordination (version 4.5). Ithaca $\mathrm{Ny}$ Usa Www (2002).

HW Nesbitt, G Markovics, RC Price. Chemical processes affecting alkalis and alkaline earths during continental weathering, Geochim Cosmochim Acta ,44(1980) 16591666.

Scull, P., \& Schaetzl, R. J. Using pca to characterize and differentiate loess deposits in wisconsin and upper michigan, usa, Geomorphology,127(3-4) (2011) 143-155.

X.Y. Li, C.C.Huang, J.1.Pang, et al. Dust source of the Holocene loess-soil and pedogenic environmental changes in the upper Huaihe River, Journal of Geography Sciences, 19 (2009) 107-117.

J.Nie, T. Stevens, M. Rittner, et al. Loess Plateau storage of Northeastern Tibetan Plateau-derived Yellow River sediment,Science Foundation in China, 6(1)(2015)8511.

R Cox,. D.R Lowe, R.L.Cullers,et al. The influence of sediment recycling and basement composition on evolution of mudrock chemistry in the southwestern United-States,Geochimica et Cosmochimica Acta, 59( 1995)2919-2940.

F.Li, G. Li, J.Chen. U-Pb ages of zircon grains reveal a proximal dust source of the Xiashu loess, Lower Yangtze River region, China,Chinese Science Bulletin, 59(2014)2391-2395. 